\title{
Hydrometallurgical Process to Recover Cobalt from Spent Li-Ion Batteries
}

\author{
Neila Djoudi *, Marie Le Page Mostefa and Hervé Muhr
}

check for updates

Citation: Djoudi, N.; Le Page Mostefa, M.; Muhr, H.

Hydrometallurgical Process to Recover Cobalt from Spent Li-Ion Batteries. Resources 2021, 10, 58. https://doi.org/10.3390/ resources 10060058

Academic Editors: Athanasios Angelis Dimakis and George Arampatzis

Received: 12 April 2021

Accepted: 18 May 2021

Published: 7 June 2021

Publisher's Note: MDPI stays neutral with regard to jurisdictional claims in published maps and institutional affiliations.
Laboratoire Réactions et Génie des Procédés (LRGP) UMR 7274 CNRS, Université de Lorraine, 1 rue Grandville BP20451, 54001 Nancy, France; marie.lepage-mostefa@univ-lorraine.fr (M.L.P.M.);

herve.muhr@univ-lorraine.fr (H.M.)

* Correspondence: neila.djoudi@univ-lorraine.fr

\begin{abstract}
The growth of the lithium-ion battery industry requires a secure supply of raw materials and appropriate end-of-life management of batteries. In almost five years, global cobalt consumption has increased by nearly $30 \%$, driven mainly by rechargeable batteries. Consequently, several risks have been identified for cobalt, in particular the growing demand for electric vehicles, which could exceed current production. Therefore, research into the recovery of this critical metal, from industrial or urban waste, is particularly important in the years to come. In this study, cobalt is recovered from a lithium-ion battery leachate in hydroxide form. The thermodynamic simulations performed with Visual Minteq showed that it was possible to recover $99.8 \%$ of cobalt (II) hydroxide at $25^{\circ} \mathrm{C}$. Based on these results, experiments were conducted to validate the hypotheses put forward and to compare the results obtained with the simulations performed. Experimentally, several operating parameters were studied to determine the optimal conditions for cobalt recovery, in terms of yield, filterability, and selectivity. Results obtained in a batch reactor allowed the determination of the temperature conditions to be applied in continuous reactor. The cobalt (II) hydroxide precipitation in continuous reactor was carried out under different $\mathrm{pH}$ conditions. It was then possible to determine the optimal conditions for cobalt recovery in terms of yield and filterability. Results showed that working at pH 9 would effectively meet the desired criteria. Indeed, cobalt recovery is close to $100 \%$ and filtration flow rate is three times higher. Results obtained allow a better understanding of cobalt (II) hydroxide precipitation.
\end{abstract}

Keywords: cobalt; hydrometallurgy; precipitation; process; li-ion battery recycling

\section{Introduction}

Many high value-added technologies contain an almost unavoidable metal: cobalt. Due to its unique properties, cobalt is used in many industrial applications such as aerospace, superalloys, and in hydrocarbon desulfurization, which is crucial for the clean fuel industry. In only five years, global consumption of cobalt has increased by almost $30 \%$, driven mainly by the rechargeable battery sector. Indeed, the lithium-ion (Li-ion) battery industry has grown exponentially since its creation at the end of the 20th century. As battery materials evolve, Li-ion battery applications are becoming more widespread. The main areas of use for Li-ion batteries include portable consumer electronics and electric/hybrid vehicles. Indeed, since 2010, Li-ion batteries have been used in hybrid and electric vehicles because of a higher power and energy density [1,2]. Approximately 2.72 million HEVs (Hybrid Electric Vehicles)/PHEVs (Plug-in Hybrid Electric Vehicles)/EV (Electric Vehicles) batteries were sold in 2015. The current market for Li-ion batteries in the automotive industry has reached more than USD 5 billion [3]. Based on the global growth of Li-ion batteries used in the automotive sector over the past five years, it is estimated that the global market for electric vehicles will reach 125 million electric vehicles by 2030 [4]. The need to reduce its environmental footprint is driving the growth for electric vehicles demand. However, this strong demand for electric vehicles could exceed current cobalt 
production capacity. When the electric vehicle market will be spread, cobalt will face increased supply risks as cobalt reserves are mostly located in one country, which is the Democratic Republic of Congo (DRC). Thus, due to significant supply risks combined with economic importance in the energy transition, cobalt has, according to the European Commission, changed from a "strategic" to a "critical" raw metal. It is more important than ever to develop new processes for efficient and sustainable cobalt recovery. Thus, it becomes necessary to secure the cobalt supply by moving towards alternative solutions such as recycling. This solution would reduce the primary metals consumption, secure the supply of raw materials and reduce waste. According to Umicore, 30,000 tons of cobalt are used each year in the batteries design, which represents about two large mines or 3-4 million electric vehicles [5]. Indeed, Tesla and Umicore have taken advantage of the reprocessing of recycled metals in batteries, claiming that the use of recycled cathode materials reduces the environmental burden of the cathode by $70 \%$. Finally, recycling saves energy because the production of metal from recycled materials uses less energy than ore processing [6].

Battery recovery processes are based on the economic benefits derived from these operations. The recycling process profitability is based on the recovery of high valueadded metals such as lithium, cobalt, nickel and manganese [7]. Several companies in North America and Europe recycle end-of-life batteries. Most Li-ion batteries come from consumer electronics and electric/hybrid vehicles. To ensure the efficiency of the battery recycling process, it is important to ensure proper collection and sorting of batteries. Metals are recovered from batteries by pyrometallurgical or/and hydrometallurgical processes.

A pyrometallurgical process is based on the treatment of batteries at high temperature, which can reach $1400^{\circ} \mathrm{C}$, where the battery cells are melted. Heavy metals such as iron, nickel, cobalt or copper are recovered in alloys form [8]. Concerning lithium and aluminum, they are not recovered because they are essentially concentrated in slag, where it is not very interesting from an energy and economic point of view. However, the slag can be used as an additive in concrete [9]. The advantage of using this type of process is that large quantities can be processed without having to sort the batteries according to their chemical composition. Only the dismantling and grinding steps are required as pretreatment. Pyrometallurgy does not allow the selective recovery of valued metals, which is why a hydrometallurgical stage is necessary. As presented in Table 1, the Umicore process is based on the hydrometallurgical treatment of the cobalt, nickel, manganese, copper and iron alloy resulting from the pyrometallurgy step, in order to separate cobalt from nickel, to recover them selectively in order to use them as battery electrode precursor [10]. Thus, cobalt is recovered as an oxide and nickel as a salt. As for lithium, pyrometallurgy does not allow its recovery; it is found in slag that is used in the concrete industry [9].

A hydrometallurgical process is based on physical and chemical operations succession, in liquid media, which allow the metal recovery. The physical steps concern the batteries safety by electrical discharge, followed by mechanical pre-treatment steps such as grinding, magnetic separation, sieving, and flotation. This operation allows the preservation of the mineral species property and separate the batteries metals. As for the chemical operations, the first stage consists of dissolving "leaching" the valued metals by acid or basic attack, in an oxidizing or reducing medium. Various inorganic acids such as $\mathrm{HCl}$, $\mathrm{H}_{2} \mathrm{SO}_{4}$ and $\mathrm{HNO}_{3}$ [11] and organic acids such as citric acid, malic acid, oxalic acid, etc. are usually used as leaching agents $[12,13]$. Then comes the second step, which is the solid-liquid separation, allowing the clarification of the leach solution by centrifugation or filtration. Finally, the last step is about the recovery of valued metals in hydroxide forms or metal salts. The techniques used to prepare the final products from the leach filtrate include solvent extraction $[14,15]$ electrochemical techniques [16,17] selective precipitation [18] and separation by ion exchange resins. This is why many hydrometallurgical processes have been developed by various companies (Accurec (Krefeld, Germany), Toxco Inc. (Annaheim, USA/ Canada), Umicore (Brusssels, Belgium), Sony (Tokyo, Japan), etc.) $[19,20]$. This process offers many advantages, as the energy consumption is low and the lithium and 
aluminum are recycled. However, the drawbacks of these processes are their long life cycle. The Table 1 summarizes the main methods and processes for recycling batteries.

Table 1. Summary of industrial technologies used in Li-ion battery recycling.

\begin{tabular}{|c|c|c|c|c|}
\hline Company & $\begin{array}{c}\text { Type of } \\
\text { Battery Treated }\end{array}$ & $\begin{array}{l}\text { Process } \\
\text { Technology }\end{array}$ & Metals Recovered & $\begin{array}{c}\text { Annual } \\
\text { Capacity } \\
\text { (Tons/Year) }\end{array}$ \\
\hline $\begin{array}{c}\text { Umicore } \\
\text { (Belgium) } \\
\text { [21] }\end{array}$ & $\begin{array}{l}\text { Li-ion, } \\
\text { NiMH }\end{array}$ & $\begin{array}{l}\text { Pyrometallurgy + } \\
\text { Hydrometallurgy }\end{array}$ & $\begin{array}{c}\mathrm{CoCl}_{2} \text { recovered } \\
\mathrm{CoCl}_{2} \text { oxidation in } \mathrm{Co}_{3} \mathrm{O}_{4} \\
\rightarrow \mathrm{LiCoO}_{2} \text { production } \\
\mathrm{NiSO}_{4} \text { recovered } \rightarrow \\
\mathrm{Ni}(\mathrm{OH})_{2}\end{array}$ & $\begin{array}{l}7000 \\
\text { tons }\end{array}$ \\
\hline $\begin{array}{c}\text { Glencore plc } \\
\text { (former Xstrata) } \\
\text { (Canada+ Norway) } \\
{[22]}\end{array}$ & Li-ion & $\begin{array}{l}\text { Pyrometallurgy + } \\
\text { Hydrometallurgy }\end{array}$ & Alloy $(\mathrm{Ni} / \mathrm{Co} / \mathrm{Cu})$ & $\begin{array}{l}7000 \\
\text { tons }\end{array}$ \\
\hline $\begin{array}{c}\text { Accurec-Recycling } \\
\text { GMbH } \\
\text { (Germany) }\end{array}$ & Li-ion, NiMH & Hydrometallurgy & $\begin{array}{l}\text { Co alloys } \\
\mathrm{Li}_{2} \mathrm{CO}_{3}\end{array}$ & $\begin{array}{l}6000 \\
\text { tons }\end{array}$ \\
\hline $\begin{array}{l}\text { Retriev Technologies } \\
\text { (USA) }[21,22]\end{array}$ & Li-metal, Li-ion & Hydrometallurgy & $\begin{array}{l}\text { Cobalt salt, } \\
\mathrm{Li}_{2} \mathrm{CO}_{3}\end{array}$ & $\begin{array}{l}4500 \\
\text { tons }\end{array}$ \\
\hline $\begin{array}{c}\text { Sumitomo- Sony } \\
\text { (Japan) } \\
{[23]}\end{array}$ & Li-ion & $\begin{array}{l}\text { Pyrometallurgy + } \\
\text { Hydrometallurgy }\end{array}$ & $\begin{array}{l}\text { Alloy }(\mathrm{Ni} / \mathrm{Co} / \mathrm{Cu}) \\
\mathrm{CoO}\end{array}$ & $\begin{array}{l}150 \\
\text { tons }\end{array}$ \\
\hline
\end{tabular}

The Li-ion battery leachate composition remains complex and requires a new recycling processes development to best meet industrial needs. In this study, the leachate studied results from an innovative and more environmentally friendly process of the material battery NMC dissolution [24]. The leachate contains copper, cobalt, nickel, manganese and lithium in sulfate media as presented in Table 2.

Table 2. Metals concentration in studied batteries leachates [24].

\begin{tabular}{cccccc}
\hline Metal & Lithium (I) & Copper (II) & Nickel (II) & Cobalt (II) & Manganese (II) \\
\hline $\begin{array}{c}\text { Concentration } \\
\left(\mathrm{mol} \mathrm{L} \mathrm{L}^{-1}\right)\end{array}$ & 0.442 & 0.259 & 0.134 & 0.131 & 0.125 \\
\hline
\end{tabular}

The separation of these metals remains a challenge in terms of cost, environmental friendliness, and efficiency. Based on the literature and the thermodynamic study carriedout with Visual Minteq 3.0 (KTH Royal Institute of Technology, Stockholm, Sweden) software, it has been possible to identify the optimum experimental conditions for cobalt (II) hydroxide recovery.

\section{Materials and Methods}

\subsection{Material}

\subsubsection{Thermodynamic Prediction on Visual Minteq 3.0 Software}

Visual Minteq 3.0 is a software for the simulation of thermodynamic equilibria, used in the calculation of metal speciation, solubility, and sorption equilibria. The advantage of using this software is the time saving, the accuracy of the results and especially the prediction of dissolution or precipitation in a complex medium, which is fundamental in this context of study. The thermodynamic database used in this software is thermos.vdb and comp_2008.vdb for inorganic species. The input data of the model are the total concentrations of the different components in solution, presented in Table 2. For all calculations, the system under study is at thermodynamic equilibrium. Thus, kinetic 
considerations are not taken into account in the simulations. The software then solves the problem in the form of non-linear algebraic equations to calculate thermodynamic chemical equilibria. Thus, Visual Minteq 3.0 evaluates the dissolution or precipitation of solid phases by calculating the supersaturation index [25].

\subsubsection{Laser Granulometry}

Particle size analysis is performed using a laser diffraction granulometer, the Malvern Mastersizer 2000 (Malvern Panalytical, Malvern, UK). This instrument allows the measurement of particle size distribution of precipitate. This technique uses a laser beam, where the particles are beforehand dispersed in water using dispersion module, to pass through this laser. Then, particles diffract the light at an angle that depends on their size. Indeed, the smaller the particle size, the larger the diffraction angle. Once a sufficient amount of sample has passed through, a particle size distribution can be plotted [26].

\subsubsection{Inductively Coupled Plasma Atomic Emission Spectrometry ICP-AES}

Inductively Coupled Plasma Spectrometry is a physical method of chemical analysis that allows the determination of different elements in solution. This technique consists of ionizing a sample using an argon plasma. Plasma is generated and maintained by a magnetic field, induced by a coil and heated to a temperature from $6000{ }^{\circ} \mathrm{K}$ to $8000{ }^{\circ} \mathrm{K}$. The spectrometer analyses the light emitted by elements contained in the sample. The liquid solution to be analyzed is brought by a peristaltic pump into a nebulizer through which a stream of argon is passed, where it is transformed into an aerosol and then filtered in the nebulization chamber [27].

\subsection{Methods}

2.2.1. Determination of the Optimum Experimental Conditions for Cobalt Hydroxide (II) Recovery

Precipitation of $\mathrm{Co}(\mathrm{OH})_{2}$ in Batch Reactor at Different Temperatures

To perform cobalt (II) precipitation with hydroxide ion: $\mathrm{Co}^{2+}+2 \mathrm{OH}^{-}=\mathrm{Co}(\mathrm{OH})_{2(\mathrm{~s})}$, the following reactants were used:

Sodium hydroxide solution: $\mathrm{NaOH}$ (99.3\%, VWR Chemicals, Radnor, USA), 1-2 mol L ${ }^{-1}$, - Cobalt (II) sulfate heptahydrate solution: $\mathrm{CoSO}_{4}, 7 \mathrm{H}_{2} \mathrm{O}(99+\%$, Acros Organics, Fair Lawn, USA), $0.131 \mathrm{~mol} \mathrm{~L}^{-1}$,

Cobalt (II) hydroxide seeds: $\mathrm{Co}(\mathrm{OH})_{2}(95+\%$, Aldrich Chemistry, Burlington, MA, USA), $50 \mathrm{~g} \mathrm{~L}^{-1}$ and $100 \mathrm{~g} \mathrm{~L}^{-1}$

The experimental set-up is composed of:

- a double-jacketed reactor of one liter, a thermostatic bath (Julabo F32-EH, Julabo, Seelbach, Germany)

a pH meter (Mettler Toledo, Columbus, OH, USA)

a stirring motor (IKA Eurostar 60 control, IKA, Staufen, Germany)

a Büchner filtration system with 0.45 or $0.22 \mu \mathrm{m}$ porosity,

laser diffraction particle size analyzer (Hydro MS 2000 Malvern)

Experiments were performed at different temperatures: $25^{\circ} \mathrm{C}, 40{ }^{\circ} \mathrm{C}, 50{ }^{\circ} \mathrm{C}, 60^{\circ} \mathrm{C}$ and $70^{\circ} \mathrm{C}$. The thermostatic bath regulates the experimental media at the desired temperature. To precipitate $3.2 \times 10^{-2} \mathrm{~mol}$ of $\mathrm{Co}^{2+}, 6.55 \times 10^{-2} \mathrm{~mol}$ of $\mathrm{OH}^{-}$are needed, which corresponds to a volume of $65.5 \mathrm{~mL}$ of soda $\left(1 \mathrm{~mol} \mathrm{~L}^{-1}\right)$. Experiment begins with the introduction of the complete volume, promptly, into the cobalt solution. Every $10 \mathrm{~min}$, for three hours, $\mathrm{pH}$ is measured, and a sample of the solution is taken, filtered, and acidified with $\mathrm{HNO}_{3}$ for ICP analyses. 


\section{Precipitation of $\mathrm{Co}(\mathrm{OH})_{2}$ in Continuous Reactor at $25^{\circ} \mathrm{C}$}

Reagents and material used for the precipitation of cobalt hydroxide in continuous reactor are the same as Section 2.2.1 The experimental set-up is identical to Section 2.2.1 the additional elements to the set-up are as follows:

- 3 peristaltic pumps

The cobalt solution $\left(0.131 \mathrm{~mol} \mathrm{~L}^{-1}\right)$ is introduced into the perfectly stirred doublejacket reactor using a peristaltic pump. The flow rate varies according to the desired $\mathrm{pH}$ in the reactor. The sodium hydroxide solution $\left(2 \mathrm{~mol} \mathrm{~L}^{-1}\right)$ is introduced at a flow rate of $3.5 \mathrm{~mL} \mathrm{~min}{ }^{-1}$. It has a concentration twice as high as that used in batch tests to reduce the dilution effect. Once the reactor volume $(500 \mathrm{~mL})$ has been reached, the withdrawal pump is witched on, thus maintaining a constant level throughout the experiment. Outlet samples are taken every $10 \mathrm{~min}$ for subsequent ICP analyses. The different flow rates are shown in the Table 3 below:

Table 3. Operating conditions in a continuous media.

\begin{tabular}{ccccc}
\hline $\mathbf{p H}$ & $\begin{array}{c}\text { The Volume Flow } \\
\text { Rate of Cobalt } \\
\left(\mathbf{m L} / \mathbf{m i n}^{-1}\right)\end{array}$ & $\begin{array}{c}\text { The Volume Flow } \\
\text { Rate of } \mathbf{~} \text { aOH } \\
\left(\mathbf{m L} / \mathbf{m i n}^{-1}\right)\end{array}$ & Time $\boldsymbol{\tau}$ (min) & $\begin{array}{c}\text { The Molar } \\
\text { Ratio } \frac{n_{\mathrm{OH}^{-}}}{n_{\mathrm{Co}^{2+}}}\end{array}$ \\
\hline 8.2 & 50 & 3.5 & 9 & 1.0 \\
\hline 8.3 & 49 & 3.5 & 9.5 & 1.1 \\
\hline 8.4 & 46 & 3.5 & 10 & 1.2 \\
\hline 8.7 & 42 & 3.5 & 11 & 1.3 \\
\hline 9.4 & 34 & 3.5 & 13 & 1.6 \\
\hline
\end{tabular}

These experiments allow the determination of the cobalt evolution of the concentration as a function of time and therefore cobalt hydroxide precipitation kinetic. Concerning particle size analyses, samples are analyzed at the end of the experiment in the same day.

\section{Results}

\subsection{Simulations Results on Batteries Leachate at Different Temperatures}

Simulations on the precipitation of metal hydroxides were carried out at different temperatures: from $25^{\circ} \mathrm{C}$ to $70^{\circ} \mathrm{C}$. The aim of these simulations is to determine the optimal temperature for total and selective cobalt recovery. The thermodynamic calculations were established based on the concentration of metals in leachate (Table 2). As a function of the temperature of the medium and the supersaturation, Visual Minteq calculates the concentrations of the precipitates formed as a function of $\mathrm{pH}$. Based on the solubility products of the different metal hydroxides at $25^{\circ} \mathrm{C}$ and on the concentrations of the metals, copper hydroxide is the most insoluble and precipitates at the lowest $\mathrm{pH}$. This is followed by the successive precipitation of nickel (II), cobalt (II) and manganese (II) hydroxides.

Simulation results of metal hydroxide precipitation at $25^{\circ} \mathrm{C}$ and $70^{\circ} \mathrm{C}$ are shown in Figure 1. At room temperature, $25^{\circ} \mathrm{C}$, nickel (II) hydroxide begins its precipitation at $\mathrm{pH} 6$ and reaches $99 \%$ at $\mathrm{pH}$ 7. It is followed by cobalt (II) hydroxide precipitation at $\mathrm{pH} 7$ and reaches $99 \%$ at $\mathrm{pH} 8$. Manganese (II) precipitates at a higher $\mathrm{pH}$ than the preceding metals. In fact, manganese (II) hydroxide precipitation begins at $\mathrm{pH} 8.4$ and reaches $99 \%$ at $\mathrm{pH} 10$. It is useful to note that copper (II) hydroxide starts its precipitation from $\mathrm{pH} 4$, as predicted by the precipitation diagram. Nevertheless, copper (II) hydroxide is highly insoluble and tends to transform into its most thermodynamically stable form, which is copper oxide [28]. According to free enthalpy values: $\Delta \mathrm{G}$ formation $\left(\mathrm{Cu}(\mathrm{OH})_{2}\right)=-28,610 \mathrm{cal} \mathrm{mol}^{-1}$ and $\Delta \mathrm{G}$ formation $(\mathrm{CuO})=-30,400 \mathrm{cal} \mathrm{mol}^{-1}$. According to various studies [24], copper oxide precipitates in a $\mathrm{pH}$ range between 4 and 7 , which is in perfect agreement with the results obtained. 

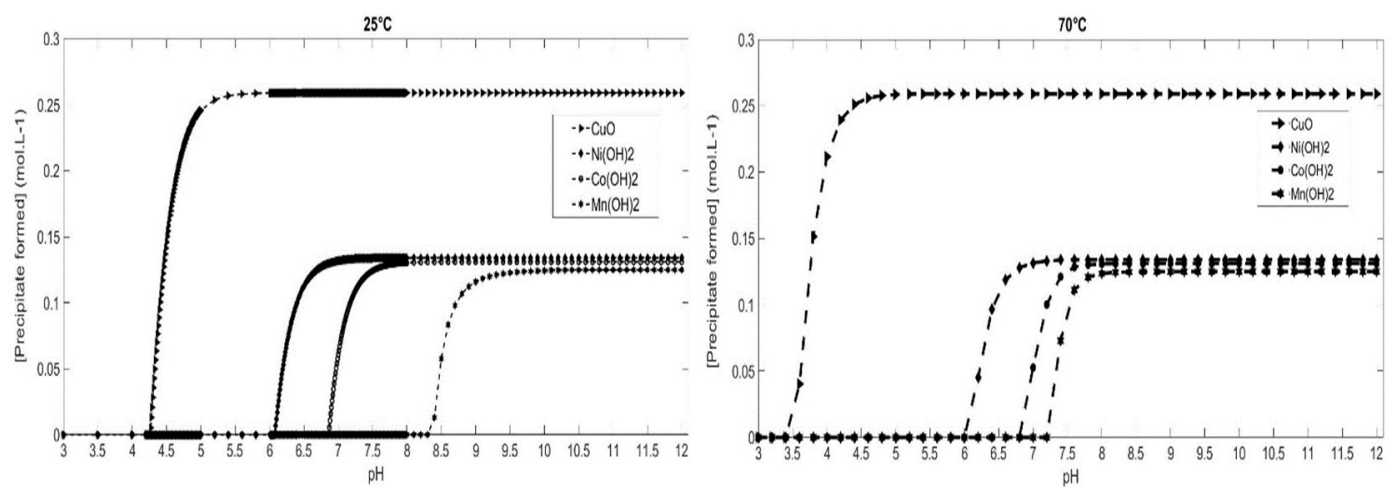

Figure 1. Precipitation of metal hydroxides at different temperatures [29]. Figure credit: N. Djoudi, M. Le Page Mostefa, and H. Muhr: Influence of Temperature on Cobalt Hydroxide Precipitation for Recovery from Battery Leachates. Chem. Eng. Technol. 2021. vol. 44, no. 6, pp. 962-971. Copyright Wiley-VCH GmbH.

Temperature does not significantly affect the $\mathrm{pH}$ formation of $\mathrm{Ni}(\mathrm{OH})_{2}$ or $\mathrm{Co}(\mathrm{OH})_{2}$. Indeed, at $25^{\circ} \mathrm{C}$ or $70{ }^{\circ} \mathrm{C}$, cobalt (II) and nickel (II) begin to precipitate at $\mathrm{pH} 6$ and $\mathrm{pH}$ 7 respectively, regardless the temperature of the solution. Nevertheless, the temperature influence is particularly important for manganese. Indeed, $\mathrm{Mn}(\mathrm{OH})_{2}$ formation starts at $\mathrm{pH}$ of 8.4 at $25{ }^{\circ} \mathrm{C}$, compared to $\mathrm{pH} 7.4$ at $70{ }^{\circ} \mathrm{C}$, which is very close to $\mathrm{Co}(\mathrm{OH})_{2}$ precipitation. As a result, it is important, according to these simulations, to not exceed the $\mathrm{pH}$ of $\mathrm{Mn}(\mathrm{OH})_{2}$ precipitation formation, if cobalt/manganese separation is based on precipitation. In addition, the most significant temperature influence is found in cobalt (II) hydroxide oxidation. Indeed, cobalt (II) precipitation at temperature higher than $40{ }^{\circ} \mathrm{C}$ has a significant impact on the thermodynamic stability of cobalt (II) hydroxide. The increase in temperature leads to a reduction in the stability range of cobalt (II) hydroxide. Cobalt hydroxide will tend to switch more rapidly to a more stable oxidized form $\left(\mathrm{Co}(\mathrm{OH})_{3}\right)$. The higher the temperature, the more the range is reduced. The cobalt will remain as $\mathrm{Co}(\mathrm{OH})_{2}$ much longer at $25^{\circ} \mathrm{C}$ than at higher temperature [30].

Thus, working at $25^{\circ} \mathrm{C}$ would allow selective cobalt recovery and theoretically slow down cobalt (II) hydroxide oxidation. Thus, according to simulations results, a hydrometallurgical process has been designed from a Li-ion battery leachate. The hydrometallurgical process is essentially and purposefully based on precipitation operations, where our process consists of recovering each element individually. This process is adaptable to the various Li-ion battery technologies, and more precisely to the chemistry of the electrodes to recover the high valued metals as well as possible.

The first step is to recover copper by adding $\mathrm{NaOH}$, under conditions of $\mathrm{pH}<6$ as it is presented in Figure 2. Then, cobalt and manganese are separated from nickel and lithium by liquid/liquid extraction. As an example, Cyanex 272-(organophosphinic acid) is the most widely used solvent extraction for the cobalt and nickel separation [31]. It has a very high selectivity allowing the efficient treatment of solutions with high nickel sulfate content and low cobalt content [32]. Subsequently, according to simulations, it is possible to separate cobalt/manganese by precipitation. However, it will be complicated to consider it experimentally. In fact, locally in the reactor, at the place where the $\mathrm{NaOH}$ is introduced, the $\mathrm{pH}$ is very high. As a result, cobalt and manganese co-precipitate, despite the homogenization of $\mathrm{pH}$ throughout the reactor. Then, an alternative solution to cobalt/manganese separation consists of an oxidative precipitation of manganese by $\mathrm{NaOCl}$. Oxidative precipitation is an interesting alternative to a conventional precipitation, provided that it is within a specific $\mathrm{pH}$ and potential range to the selective precipitation of manganese oxide. For a potential range between 1.0 and $1.2 \mathrm{~V}$ (vs Standard hydrogen electrode) and a pH between 1 and 3, cobalt remains in the soluble $\mathrm{Co}^{2+}$ state while the stable form of manganese is solid $\mathrm{MnO}_{2}$. Indeed, in the $\mathrm{pH}$ range between 3 and 4 and in the same potential range, cobalt predominates as $\mathrm{Co}(\mathrm{OH})_{3}$ or $\mathrm{Co}_{2} \mathrm{O}_{3}, 3 \mathrm{H}_{2} \mathrm{O}$ [33]. After that, cobalt is recovered by adding $\mathrm{NaOH}$ solution, $\mathrm{pH}$ range will be related to the polymorph 
aimed to precipitate: $\alpha-\mathrm{Co}(\mathrm{OH})_{2}$ or $\beta-\mathrm{Co}(\mathrm{OH})_{2}$. As for nickel, it is precipitated in the same way at a pH between 6 and 7. Lithium is recovered by the addition of sodium carbonate as mentioned in the literature [34], until saturation and crystallization of lithium carbonate.

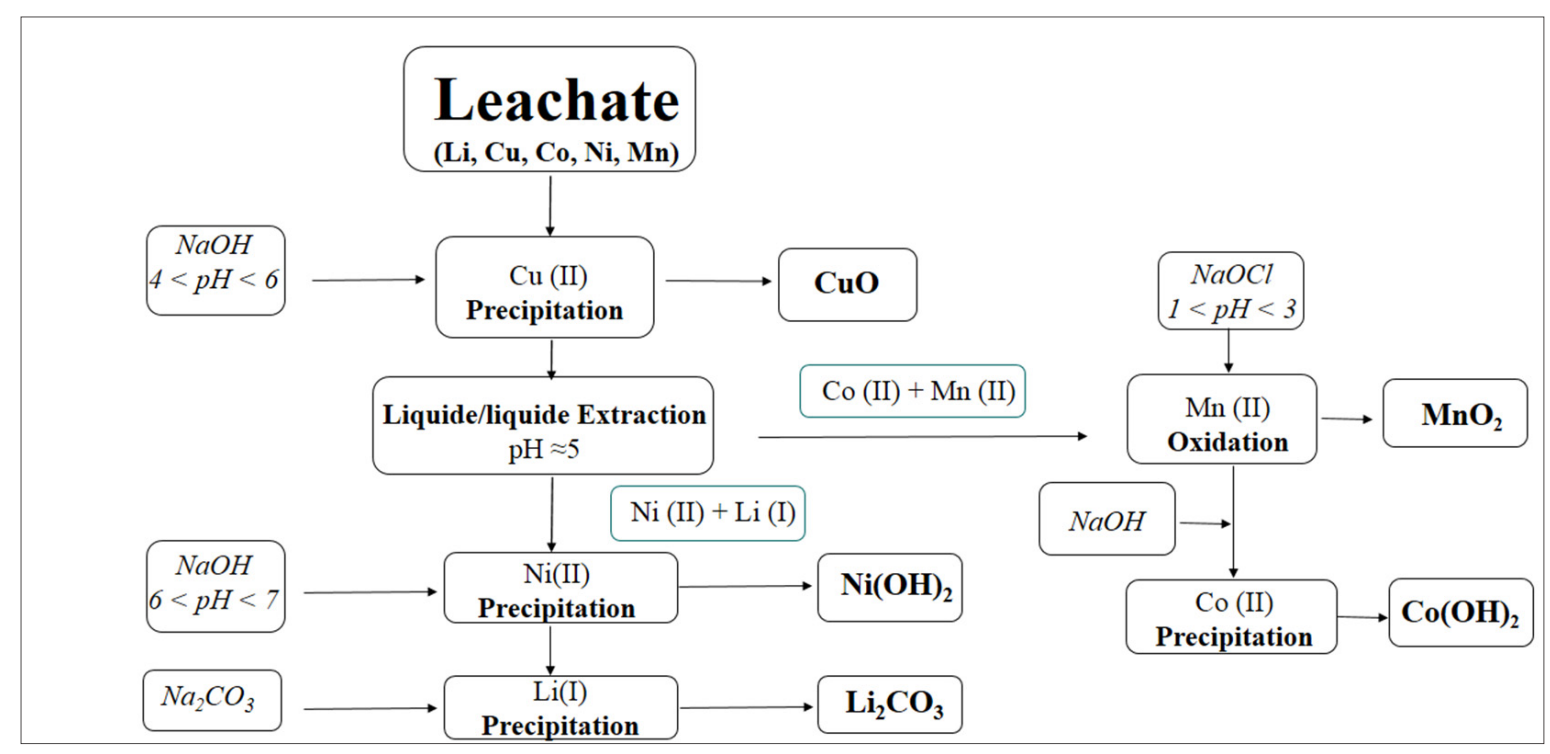

Figure 2. Hydrometallurgical process designed to recover Cobalt from Li-ion batteries leachate.

The simulation results showed that it was possible to recover $99.8 \%$ of cobalt, in the hydroxide form. Indeed, at $\mathrm{pH} 8,\left[\mathrm{Co}(\mathrm{OH})_{2}\right]=0.1307 \mathrm{~mol} \mathrm{~L}^{-1}$. Based on these simulations results, experiments were conducted to validate the hypotheses put forward and to compare the results obtained with the simulations performed. Experimentally, several parameters were studied to determine the best conditions for cobalt recovery, in terms of yield, filterability, and selectivity. The selected polymorph should allow the obtaining of the highest yields and the lowest filtration times, thus growing closer to the real conditions of Li-ion battery leachates, and appearing on the proposed process scheme.

3.2. Determination of the Optimum Experimental Conditions for Cobalt Hydroxide (II) Recovery 3.2.1. Precipitation of $\mathrm{Co}(\mathrm{OH})_{2}$ in Batch Reactor at Different Temperatures Temperature's Influence on Cobalt (II) Hydroxide Recovery

The temperature increase accelerates the phase transition from $\alpha-\mathrm{Co}(\mathrm{OH})_{2}$ to $\beta$ $\mathrm{Co}(\mathrm{OH})_{2}$ and cobalt recovery is optimal at $25{ }^{\circ} \mathrm{C}$ with a yield close to $100 \%$ (Figure 3) [29]. Indeed, at $25{ }^{\circ} \mathrm{C}$, after $28 \mathrm{~min}, 99.98 \% \pm 0.02 \%$ of the cobalt is in $\beta-\mathrm{Co}(\mathrm{OH})_{2}$ form. In comparison, at $70{ }^{\circ} \mathrm{C}$, in only $4 \mathrm{~min}, 99.8 \% \pm 0.02 \%$ of the cobalt has precipitated. In addition, a slight decrease in cobalt yield can be observed over time. This could be explained by $\mathrm{Co}(\mathrm{OH})_{2}$ oxidation with oxygen from the air. When supersaturation, which is the driving force of precipitation, is sufficiently high, cobalt precipitates as $\beta-\mathrm{Co}(\mathrm{OH})_{2}$. It is useful to note that $\alpha-\mathrm{Co}(\mathrm{OH})_{2}$ is the less stable polymorph in a thermodynamical point of view and tends to transform into the most stable polymorphic form: $\beta-\mathrm{Co}(\mathrm{OH})_{2}$ [35]. In Figure 3 , the cobalt recovery is stabilized from 16 to $30 \mathrm{~min}$, because of $\alpha-\mathrm{Co}(\mathrm{OH})_{2}$ dissolution is compensated with $\beta-\mathrm{Co}(\mathrm{OH})_{2}$ particles growth. In fact, as $\beta-\mathrm{Co}(\mathrm{OH})_{2}$ particles gradually form, their growth consumes the solute. From 36 min onwards, the cobalt concentration slowly decreases at $25{ }^{\circ} \mathrm{C}$ compared to temperatures higher [29]. This can be explained by the progressive oxidation of $\beta-\mathrm{Co}(\mathrm{OH})_{2}$ to cobalt oxyhydroxide $\mathrm{CoOOH}$, which is in line with various studies results [36,37]. Indeed, at high temperatures, oxidation occurs more rapidly, in less than $8 \mathrm{~min}$ and more importantly. The increase in temperature has the effect of reducing supersaturation, due to the increase in solubility products, and thus, of promoting the progressive dissolution of $\mathrm{Co}(\mathrm{OH})_{2}$ particles. Previous work has shown that oxidation also occurs by a dissolution-precipitation mechanism [38,39]. The quantity of 
cobalt in solution will thus increase with temperature, the yield of the precipitated cobalt (II) will thus slightly decrease.

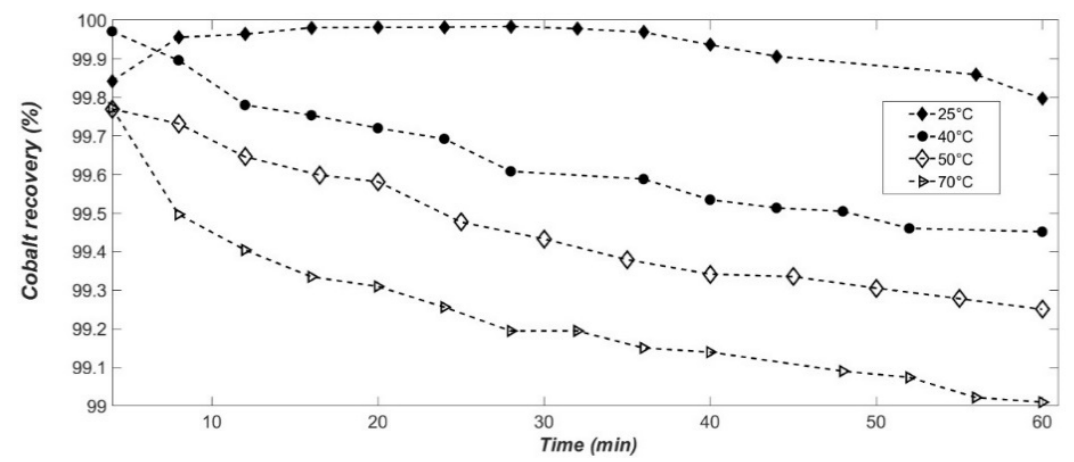

Figure 3. Cobalt recovery over time at different temperatures [29]. Figure credit: N. Djoudi, M. Le Page Mostefa, and H. Muhr: Influence of Temperature on Cobalt Hydroxide Precipitation for Recovery from Battery Leachates. Chem. Eng. Technol.2021. vol. 44, no. 6, pp. 962-971. Copyright Wiley-VCH GmbH.

Experimental results show that the temperature increase leads to a faster decrease in pH over time as displayed in Figure 4, which could be explained by the Co (II) hydroxide oxidation. Indeed, according to various research studies, the cobalt (II) hydroxide oxidation may be explained by proton diffusion, which corresponds to a decrease in $\mathrm{pH}$ [38]. Therefore, the rapid decrease in $\mathrm{pH}$ at high temperature is related to the oxidation reaction acceleration. Experiments conducted at $50{ }^{\circ} \mathrm{C}$ have confirmed this observation, where cobalt (II) hydroxide precipitation were conducted under nitrogen conditions [29]. Several simulations of precipitation of metal hydroxides contained in battery leachates show that care must be taken at the chosen temperature, whether manganese/cobalt separation is conducted by precipitation with hydroxides. Thus, $\mathrm{Mn}(\mathrm{OH})_{2}$ precipitates at $\mathrm{pH}$ close to the $\mathrm{Co}(\mathrm{OH})_{2}$ precipitation. To avoid manganese co-precipitation and according to the results of the simulations, it is advisable to work at temperatures close to room temperature, $25^{\circ} \mathrm{C}$. Moreover, this temperature's choice is in perfect agreement with literature. Indeed, working at temperatures higher than $25^{\circ} \mathrm{C}$ promotes considerably the cobalt (II) hydroxide oxidation, which is not interesting in terms of yield and precipitates evolution.

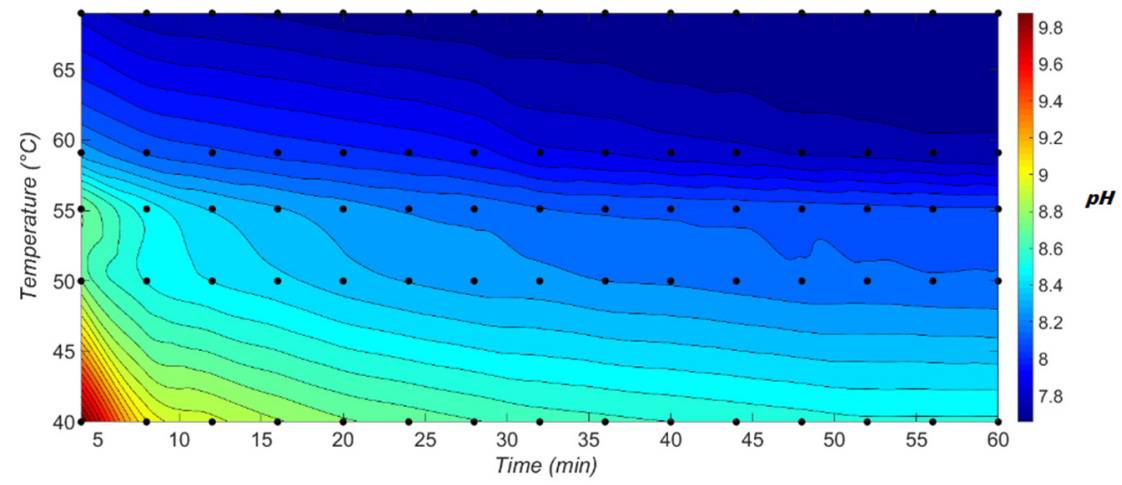

Figure 4. pH evolution over time at different temperatures [29]. Figure credit: N. Djoudi, M. Le Page Mostefa, and H. Muhr: Influence of Temperature on Cobalt Hydroxide Precipitation for Recovery from Battery Leachates. Chem. Eng. Technol. 2021. vol. 44, no. 6, pp. 962-971. Copyright Wiley-VCH GmbH.

Temperature's Influence on Cobalt (II) Hydroxide Granulometry

Concerning temperature's influence on particle size distribution, experimental results show that increasing the temperature results in smaller particles of $\beta-\mathrm{Co}(\mathrm{OH})_{2}$ as shown in Figure 5. Indeed, at $25^{\circ} \mathrm{C}$, the cut-off diameter $\left(\mathrm{d}_{50}\right)$ of $\mathrm{Co}(\mathrm{OH})_{2}$ particles is about $30 \mu \mathrm{m}$. In comparison, this diameter decreases by $55 \%$ at $70{ }^{\circ} \mathrm{C}$, as $\mathrm{d}_{50}=13 \mu \mathrm{m}$. However, this 
decrease varies slightly between $40{ }^{\circ} \mathrm{C}$ and $70{ }^{\circ} \mathrm{C}$, with a particle cut-off diameter of about $16 \mu \mathrm{m}$.

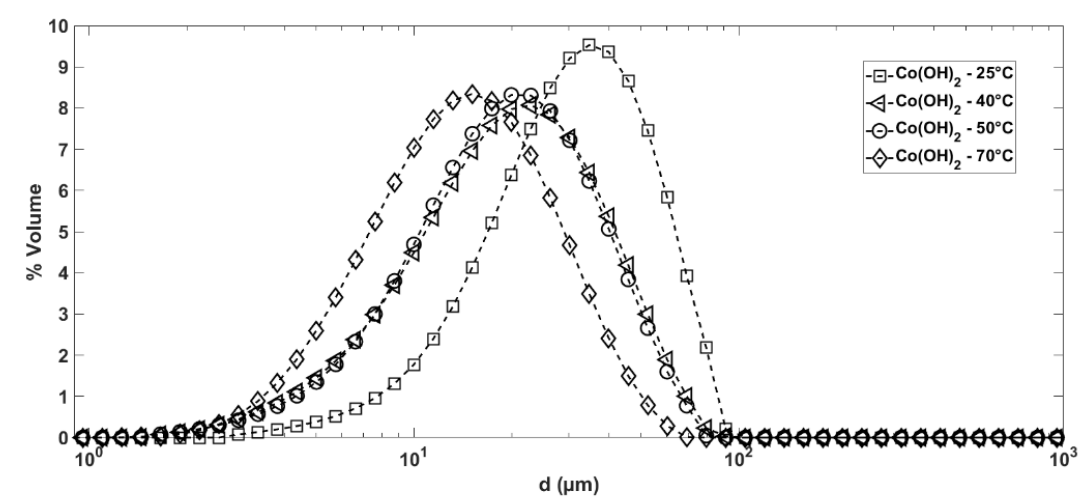

Figure 5. Particle size distribution at different temperatures. Figure credit: N. Djoudi, M. Le Page Mostefa, and H. Muhr: Influence of Temperature on Cobalt Hydroxide Precipitation for Recovery from Battery Leachates. Chem. Eng. Technol.2021. vol. 44, no. 6, pp. 962-971. Copyright Wiley-VCH GmbH.

The particle size decrease depends significantly on the temperature increase. These conditions may therefore not be favorable to the agglomeration mechanism. To highlight this transformation, the particle number size distribution at $25^{\circ} \mathrm{C}$ and $70{ }^{\circ} \mathrm{C}$ is displayed in Figure 6. The shift from a volume size distribution $\mathrm{g}(\mathrm{L})$ (Figure 5) to a number size distribution $\mathrm{n}(\mathrm{L})$ is done using a constant. Starting from the mass concentration expression (Cc) of the crystals in suspension, it is then possible to determine this constant which makes it possible to link the size distributions.

$$
C_{c}=\varphi_{v} \rho_{c} \int_{0}^{\infty} \bar{L}^{3} n(L) d L \Leftrightarrow \frac{1}{\int_{0}^{\infty} L^{3} n(L) d L}=\frac{\varphi_{v} \rho_{c}}{C_{c}}
$$

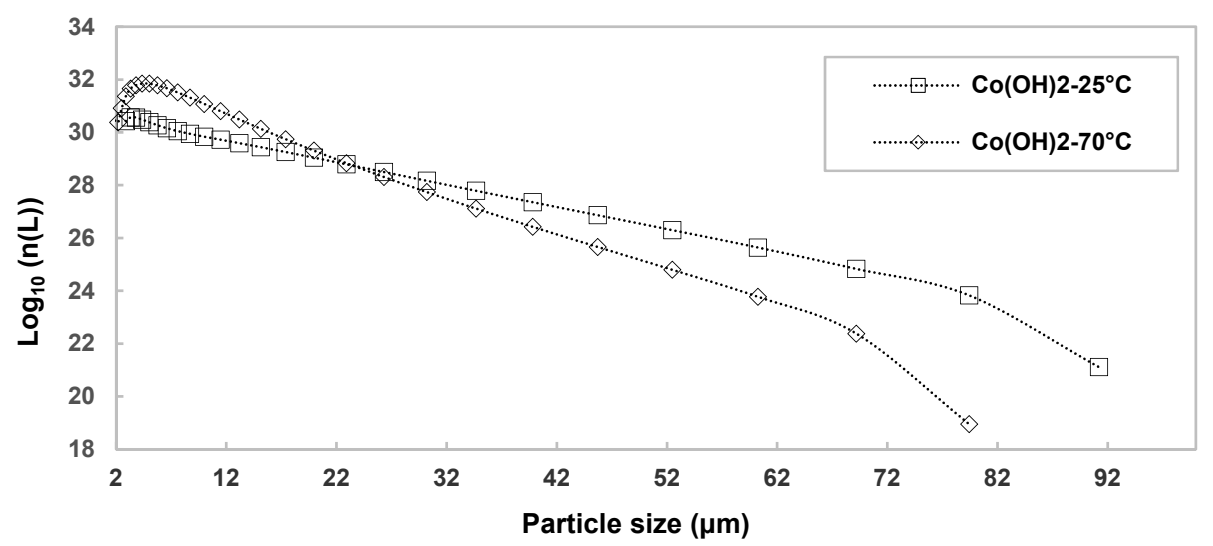

Figure 6. Particle number size distribution at $25^{\circ} \mathrm{C}$ and $70^{\circ} \mathrm{C}$.

Considering that for a volume of suspension given:

$$
d m=V \varphi_{v} \rho_{c} \bar{L}^{3} d N=V \varphi_{v} \rho_{c} \bar{L}^{3} n(L) d L
$$

Then:

$$
\begin{gathered}
m_{t}=V \varphi_{v} \rho_{c} \int_{0}^{\infty} \bar{L}^{3} n(L) d L \\
g(L)=\frac{d m}{d L} \frac{1}{m_{t}}=\frac{V \varphi_{v} \rho_{c} L^{3} n(L) d L}{V \varphi_{v} \rho_{c} \int_{0}^{\infty} L^{3} n(L) d L}\left(\frac{1}{d L}\right)=\frac{\bar{L}^{3} n(L)}{\int_{0}^{\infty} \bar{L}^{3} n(L) d L}
\end{gathered}
$$


By combining Equation (1) in Equation (4), $g(L)$ expression form is the following:

$$
g(L)=\bar{L}^{3} \frac{\varphi_{v} \rho_{c}}{C_{c}} n(L)
$$

Then:

$$
n(L)=g(L) \frac{C_{c}}{\varphi_{v} \rho_{c} \bar{L}^{3}}
$$

With:

$\begin{array}{cc}\varphi_{v}: & \text { Volume form factor } \\ n(L): & \text { Number size distribution }\left(\mathrm{m}^{-4}\right) \\ C_{c}: & \text { Mass concentration of crystals }\left(\mathrm{kg} \cdot \mathrm{m}^{-3}\right) \\ m_{c}: & \text { Mass of crystalline particle }(\mathrm{kg}) \\ \rho_{c}: & \text { Density of crystalline particle }\left(\mathrm{kg} \cdot \mathrm{m}^{-3}\right) \\ \bar{L}: & \text { Average particle size }(\mu \mathrm{m}) \\ m_{t}: & \text { Total sample mass of the precipitate }(\mathrm{kg})\end{array}$

As displayed in Figure 6, the fine particles number is significantly higher at $70{ }^{\circ} \mathrm{C}$ than at $25^{\circ} \mathrm{C}$, which has an impact on the precipitate filterability. At $70^{\circ} \mathrm{C}$, the filtration of the precipitate is very difficult, with a strong increase in pressure drop and a long filtration time. It should be remembered that the solubility of $\mathrm{Co}(\mathrm{OH})_{2}$ increases as a function of temperature, as do the reaction kinetics. Thus, supersaturation decreases more rapidly over time at $70{ }^{\circ} \mathrm{C}$ than at $25{ }^{\circ} \mathrm{C}$, which is detrimental to particle agglomeration. On the other hand, an increase in temperature favors the $\mathrm{Co}(\mathrm{OH})_{2}$ particles oxidation. The oxidation mechanism takes place in two stages, dissolution and precipitation. The cobalt (II) hydroxide particles dissolve and then precipitate as smaller particles. Thus, these conditions are unfavorable both from a kinetic and particle size point of view.

It is, therefore, recommended to work at temperatures close to room temperature to limit oxidation, maintain a very good cobalt (II) yield and control the particle size, which is a fundamental parameter for the filtration and washing stages. It should be noted that operating at room temperature allows the proposal of a low-energy-consuming process, without thermal risks and with lower implementation and operating costs. In addition, working at $40^{\circ} \mathrm{C}$ or higher would generate the formation of particles with a cut-off diameter of about $17 \mu \mathrm{m}$ versus $34 \mu \mathrm{m}$ at $25^{\circ} \mathrm{C}$. Consequently, working at low temperature allows validation of all the criteria sought: selectivity, yield, and filterability.

\subsection{Precipitation of $\mathrm{Co}(\mathrm{OH})_{2}$ in Continuous Reactor at $25^{\circ} \mathrm{C}$}

The $\mathrm{Co}(\mathrm{OH})_{2}$ precipitation was first studied in a discontinuous regime to determine the operating parameters to achieve the established objectives. Indeed, it was concluded to work at $25^{\circ} \mathrm{C}$ to slow down the $\mathrm{Co}(\mathrm{OH})_{2}$ oxidation. Moreover, this temperature was also chosen based on the different unit operations that take place with the recovery of cobalt (II) in the hydrometallurgical process, the liquid/liquid extraction and the cobalt/manganese separation. The second parameter that has been studied is the reaction time: it only takes a few minutes for the cobalt to precipitate at more than $99.9 \%$. However, the polymorphic transition is slightly longer (about $20 \mathrm{~min}$ ). Nevertheless, the product obtained is stable and does not evolve over time. Since filtration takes place during the day, oxidation is not a problem for the cobalt yield or even for the stability of the powder obtained. The particle size quality obtained is essential for the subsequent use of the cobalt. Thus, the study was carried out over a $\mathrm{pH}$ range from 8.2 to 9.4 to avoid $\mathrm{Co}(\mathrm{OH})_{2}$ oxidation and to determine the optimal $\mathrm{pH}$, whose control is essential to meet the best recovery and filterability.

The experiments were conducted in a $\mathrm{pH}$ range between 8.2 and 9.4, corresponding to a molar ratio $\mathrm{n} \mathrm{OH}^{-} / \mathrm{n} \mathrm{Co}^{2+}<2$. The experiments showed that for a molar ratio lower than 2, cobalt (II) hydroxide of type $\alpha-\mathrm{Co}(\mathrm{OH})_{2}$ is formed. Indeed, supersaturation is not sufficient for the rapid polymorphic transition from $\alpha-\mathrm{Co}(\mathrm{OH})_{2}$ to $\beta-\mathrm{Co}(\mathrm{OH})_{2}$ [40]. Studies have shown that for a molar ratio $\mathrm{n} \mathrm{OH}^{-} / \mathrm{n} \mathrm{Co}^{2+}$ between 1 and 1.8 , the polymorph $\alpha-\mathrm{Co}(\mathrm{OH})_{2}$ 
remained stable, its conversion to the $\beta-\mathrm{Co}(\mathrm{OH})_{2}$ form is very long. Experimentally, the cobalt (II) hydroxide precipitation under these conditions leads to a polymorphic transition of up to $70 \mathrm{~h}$. On the other hand, for a molar ratio greater than or equal to $2, \alpha-\mathrm{Co}(\mathrm{OH})_{2}$ transforms quite rapidly into $\beta-\mathrm{Co}(\mathrm{OH})_{2}$ [36], a transition time of about two hours has been observed. Thus, it is interesting to study the behavior of $\alpha-\mathrm{Co}(\mathrm{OH})_{2}$ in a continuous regime and in a varied $\mathrm{pH}$ range, which depends mainly on the molar ratio $\mathrm{n} \mathrm{OH}^{-} / \mathrm{n}$ $\mathrm{Co}^{2+}<2$. This study will allow the determination of the optimal $\mathrm{pH}$ that will meet the criteria of yield and filterability. The results in terms of cobalt recovery yield as a function of $\mathrm{pH}$ are shown in Figure 7.

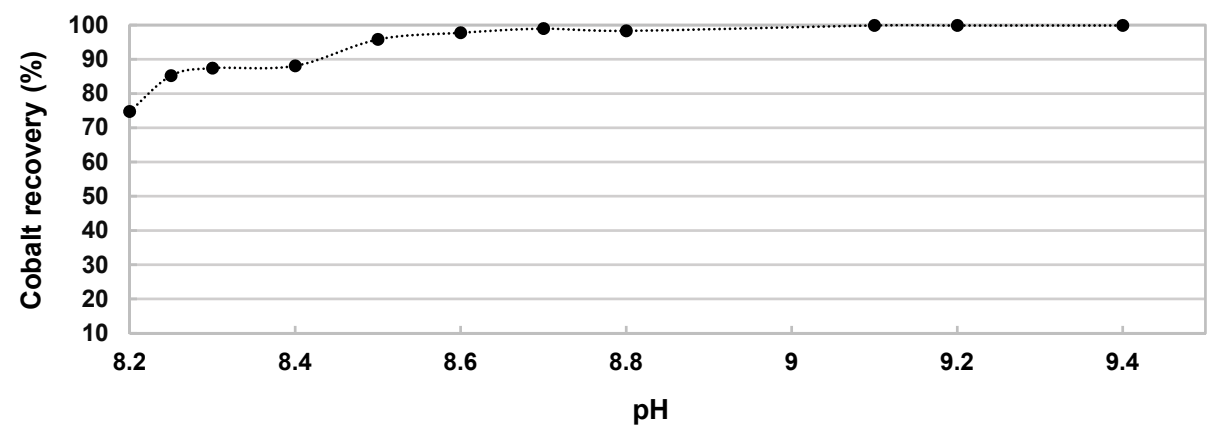

Figure 7. Cobalt recovery at different $\mathrm{pH}$.

It appears that the cobalt recovery yield at $\mathrm{pH} 8.3$ is around $90 \%$. The recovery is not total because this $\mathrm{pH}$ corresponds to a molar ratio $\mathrm{n} \mathrm{OH}^{-} / \mathrm{n} \mathrm{Co}^{2+}$ of 1.1 , which is not enough to recover all cobalt in solution. Thus, the total precipitation of cobalt starts from $\mathrm{pH} 8.6$ where $98 \%$ of cobalt is in $\alpha-\mathrm{Co}(\mathrm{OH})_{2}$ form. Cobalt is recovered totally in a pH range between 8.6 and 9.4. It should be noted that in this range, the molar ratio $\mathrm{n} \mathrm{OH}^{-} / \mathrm{n} \mathrm{Co}^{2+}$ is between 1.3 and 1.6. It is useful to note that the solid formed under this $\mathrm{pH}$ condition could correspond to a $\mathrm{Co}(\mathrm{OH}) \mathrm{x} ; 1.3<\mathrm{x}<1.6$ form, due to the $\alpha-\mathrm{Co}(\mathrm{OH})_{2}$ hydrotalcite structure, which mean the quantity of soda used is reduced, which is quite promising in economic point of view. From a particle size point of view (Figure 8), it appears that the $\mathrm{pH}$ increase causes a decrease in the median particle diameter of the $\mathrm{Co}(\mathrm{OH})_{2}$ particles. Indeed, for a $\mathrm{pH}$ of 8.2 the median diameter is $42 \mu \mathrm{m} \pm 1.5 \mu \mathrm{m}$ and it increases to $23 \mu \mathrm{m} \pm 0.04 \mu \mathrm{m}$ for a $\mathrm{pH}$ of 9.4 .

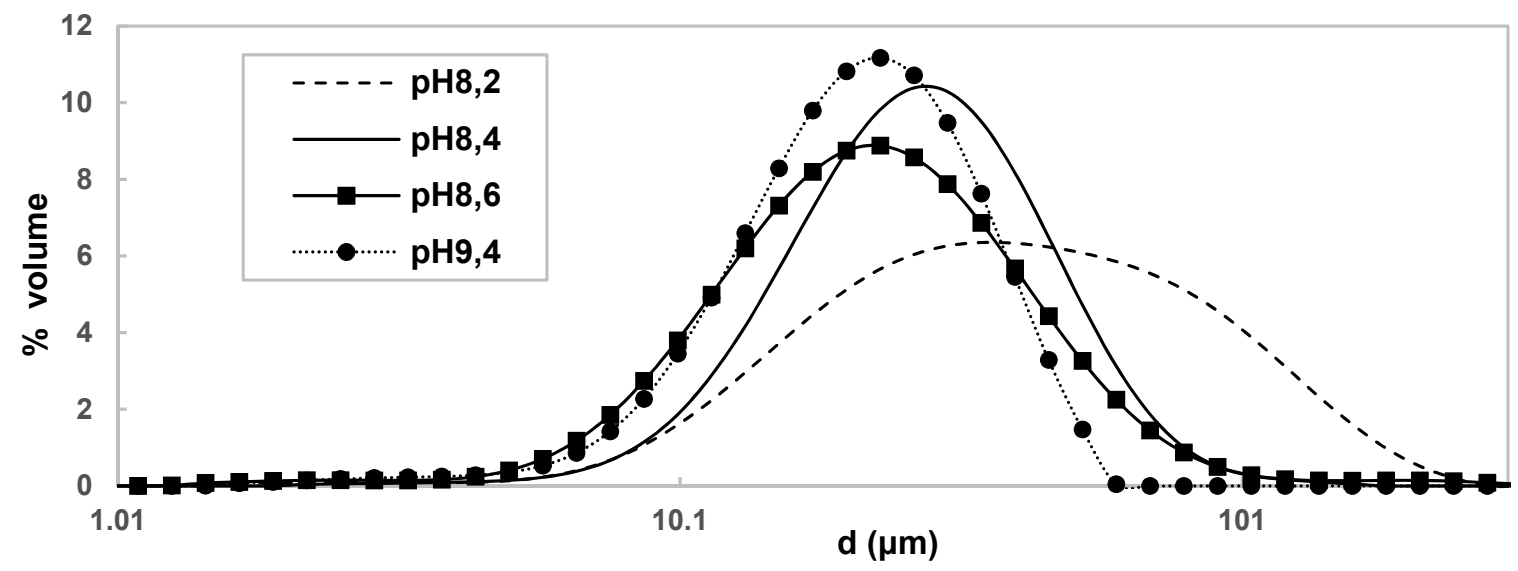

Figure 8. Particle size distribution at different $\mathrm{pH}$.

In terms of filterability, at $\mathrm{pH}=9.4$, filtration takes place at a flow rate of $100 \mathrm{~mL} \cdot \mathrm{min}^{-1}$

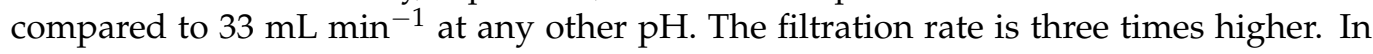
addition, the polymorph control is a major issue. Comparing the different nucleation rates, it appears that in a range of $\mathrm{pH}<9.4$, nucleation rates increase, as shown in Figure 9. 


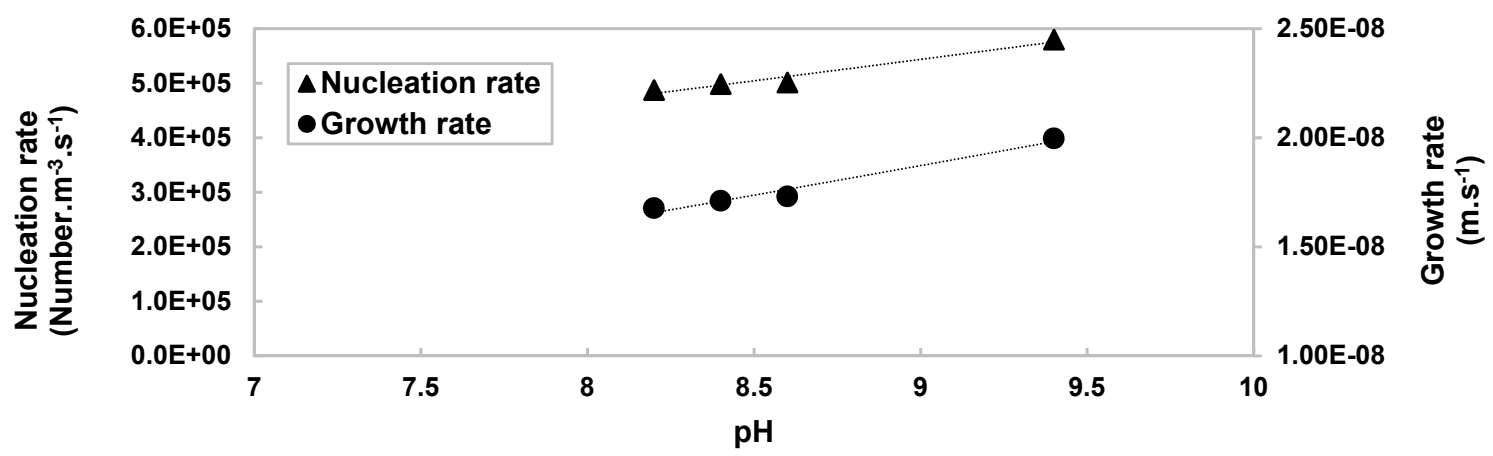

Figure 9. Nucleation and growth rate in function of $\mathrm{pH}$.

This is supported by the fact that as the $\mathrm{pH}$ rises, the amount of $\mathrm{OH}^{-}$increases, which promotes nucleation. However, depending on the available supersaturation, nucleation may be limited, and growth promoted. This range corresponds well to the molar ratio $\mathrm{n} \mathrm{OH}^{-} / \mathrm{n} \mathrm{Co}^{2+}<2$, where the $\alpha-\mathrm{Co}(\mathrm{OH})_{2}$ form predominates. Nevertheless, at $\mathrm{pH} 9.4$ the trend is more pronounced, the nucleation rate increases sharply in contrast to the growth rate which decreases. This can be explained by $\alpha-\mathrm{Co}(\mathrm{OH})_{2}$ which will tend to transform into its $\beta-\mathrm{Co}(\mathrm{OH})_{2}$ form when precipitation conditions are close. It could be that for a $\mathrm{pH}$ of $9, \alpha-\mathrm{Co}(\mathrm{OH})_{2}$ is in the transformation phase, so it acquires the properties of both polymorphs.

Consequently, the solid $\alpha-\mathrm{Co}(\mathrm{OH})_{2}$ filtration takes place relatively quickly, the $\beta$ $\mathrm{Co}(\mathrm{OH})_{2}$ transition does not occur under these conditions. In addition, the polymorph $\alpha-\mathrm{Co}(\mathrm{OH})_{2}$ has several advantages such as its hydrotalcite crystal structure. Indeed, it has a larger interlayer space, which gives it much better electrochemical capabilities [41]. Consequently, it is necessary to work at $\mathrm{pH} 9.4$ to recover all cobalt in solution and to filter optimally. In addition, working at $\mathrm{pH} 9$ limits the quantities of soda added, the molar ratio between soda and cobalt is 1.6 against 2 theoretically, which remains interesting from an economic point of view.

\section{Conclusions}

In this study, it was possible to determine the most favorable conditions for the cobalt (II) hydroxide precipitation, based on simulations and experimental results. The temperature increase accelerates the phase transition from $\alpha-\mathrm{Co}(\mathrm{OH})_{2}$ to $\beta-\mathrm{Co}(\mathrm{OH})_{2}$ and the cobalt recovery is optimal at $25^{\circ} \mathrm{C}$ with a yield close to $100 \%$. Experimental results show that the temperature increase leads to a faster decrease in $\mathrm{pH}$ over time, which could be explained by the Co (II) hydroxide oxidation. According to various research studies, the cobalt (II) hydroxide oxidation is accompanied by proton diffusion, which corresponds to a decrease in $\mathrm{pH}$. Therefore, the rapid decrease in $\mathrm{pH}$ at high temperature is probably related to the acceleration of the oxidation reaction. Various simulations for battery leachates show that care must be taken at the chosen temperature, because at high temperature, Mn (II) hydroxide precipitates at $\mathrm{pH}$ levels close to the precipitation of Co (II) hydroxide, in the case of cobalt/manganese separation by precipitation. According to the simulations results, it is advisable to work at temperatures close to room temperature, to avoid manganese co-precipitation. Moreover, this temperature is in perfect agreement with the best cobalt precipitation yields and with the results of the particle size distribution, which is favorable to a better filterability. Working at $40{ }^{\circ} \mathrm{C}$ and above would generate the formation of particles with a median diameter of about $17 \mu \mathrm{m}$ versus $34 \mu \mathrm{m}$ at $25^{\circ} \mathrm{C}$. Consequently, working at low temperature allows validation of all the criteria sought: selectivity, yield, and filterability.

Subsequently, the cobalt (II) hydroxide precipitation was studied in a continuous reactor. The optimal operating conditions determined in batch mode constituted the starting point for the continuous precipitation and for the rest of the work. The continuous precipitation of cobalt (II) hydroxide was carried out under different $\mathrm{pH}$ conditions to 
determine the optimal $\mathrm{pH}$ to best meet the desired criteria (yield and filterability). Working at $\mathrm{pH}=9$ allows the recovery of all the cobalt in the form $\alpha-\mathrm{Co}(\mathrm{OH})_{2}$, to filter quickly and to limit the quantities of soda added. Indeed, the molar ratio between soda ash and cobalt is 1.6 against 2 for $\beta-\mathrm{Co}(\mathrm{OH})_{2}$, which is interesting from an economic point of view. These cobalt (II) recovery conditions allow the determination of the optimal cobalt (II) hydroxide precipitation conditions in terms of yield, filterability, and polymorphism. This promising result allows the consideration of cobalt (II) hydroxide precipitation on a larger scale as fluidized bed reactor for example. Indeed, the fluidized bed reactor should guarantee a larger granulometry and thus a better filterability, which represents one of the main conditions of this study. Then, it will be possible to extend this study in an industrial scale for different type of Li-ion battery leachate.

Author Contributions: Writing-original draft preparation, N.D.; writing-review and editing, M.L.P.M., H.M. All authors have read and agreed to the published version of the manuscript.

Funding: This research received no external funding.

Institutional Review Board Statement: Not applicable.

Informed Consent Statement: Not applicable.

Conflicts of Interest: The authors declare no conflict of interest.

\section{References}

1. Broussely, M. Lithium-Ion Batteries for Ev, Hev and other Industrial Applications. In Lithium Batteries: Science and Technology; Nazri, G.-A., Pistoia, G., Eds.; Springer: Boston, MA, USA, 2003; pp. 645-685. ISBN 978-0-387-92675-9.

2. Gaines, L. The future of automotive lithium-ion battery recycling: Charting a sustainable course. Sustain. Mater. Technol. 2014, 1-2, 2-7. [CrossRef]

3. Heelan, J.; Gratz, E.; Zheng, Z.; Wang, Q.; Chen, M.; Apelian, D.; Wang, Y. Current and Prospective Li-Ion Battery Recycling and Recovery Processes. JOM 2016, 68, 2632-2638. [CrossRef]

4. Akutagawa, K.; Wakao, Y. Stabilization of Vehicle Dynamics by Tire Digital Control—Tire Disturbance Control Algorithm for an Electric Motor Drive System. World Electr. Veh. J. 2019, 10, 25.

5. Hagelüken, C. Critical Metals for Lithium-Ion. Batteries-Umicore strategies for sustainable sourcing of Cobalt. Resour. Future Gener. 2018. [CrossRef]

6. Forfar, J. Tesla's Approach to Recycling is the Way of the Future for Sustainable Production. Available online: https:/ / medium. $\mathrm{com} /$ tradr/teslas-approach-to-recycling-is-the-way-of-the-future-for-sustainable-production-5af99b62aa0e (accessed on 26 February 2021).

7. Face au Défi des Métaux Critiques, Une Approche Stratégique du Recyclage S'impose. Available online: https:/ /www.ifri.org/fr/ publications / editoriaux-de-lifri/edito-energie/face-defi-metaux-critiques-une-approche-strategique (accessed on 26 February 2021).

8. Georgi-Maschler, T.; Friedrich, B.; Weyhe, R.; Heegn, H.; Rutz, M. Development of a recycling process for Li-ion batteries. J. Power Sources 2012, 207, 173-182. [CrossRef]

9. Dunn, J.B.; Gaines, L.; Barnes, M.; Wang, M.; Sullivan, J. Material and Energy Flows in the Materials Production, Assembly, and End-of-Life Stages of the Automotive Lithium-Ion Battery Life Cycle; Argonne National Lab (ANL): Argonne, IL, USA, 2012.

10. Frédéric, C.; Geldron, A.; Villeneuve, J.; Gaboriau, H. Economie circulaire et recyclage des métaux. Géosciences 2012, 15, 64-71.

11. Meshram, P.; Abhilash, D.; Pandey, B.; Mankhand, T.; Deveci, H. Comparision of Different Reductants in Leaching of Spent Lithium Ion Batteries. J. Met. 2016, 68. [CrossRef]

12. Chen, X.; Zhou, T. Hydrometallurgical process for the recovery of metal values from spent lithium-ion batteries in citric acid media. Waste Manag. Res. 2014, 32, 1083-1093. [CrossRef]

13. Li, L.; Bian, Y.; Zhang, X.; Guan, Y.; Fan, E.; Wu, F.; Chen, R. Process for recycling mixed-cathode materials from spent lithium-ion batteries and kinetics of leaching. Waste Manag. 2018, 71, 362-371. [CrossRef]

14. Chen, L.; Tang, X.; Zhang, Y.; Li, L.; Zeng, Z.; Zhang, Y. Process for the recovery of cobalt oxalate from spent lithium-ion batteries. Hydrometallurgy 2011, 108, 80-86. [CrossRef]

15. Jha, M.K.; Kumari, A.; Jha, A.K.; Kumar, V.; Hait, J.; Pandey, B.D. Recovery of lithium and cobalt from waste lithium ion batteries of mobile phone. Waste Manag. 2013, 33, 1890-1897. [CrossRef]

16. Lupi, C.; Pasquali, M.; Dell'Era, A. Nickel and cobalt recycling from lithium-ion batteries by electrochemical processes. Waste Manag. 2005, 25, 215-220. [CrossRef] [PubMed]

17. Prabaharan, G.; Barik, S.P.; Kumar, N.; Kumar, L. Electrochemical process for electrode material of spent lithium ion batteries. Waste Manag. 2017, 68, 527-533. [CrossRef]

18. Wang, R.-C.; Lin, Y.-C.; Wu, S.-H. A novel recovery process of metal values from the cathode active materials of the lithium-ion secondary batteries. Hydrometallurgy 2009, 99, 194-201. [CrossRef] 
19. Meshram, P.; Pandey, B.; Mankhand, T. Extraction of lithium from primary and secondary sources by pre-treatment, leaching and separation: A comprehensive review. Hydrometallurgy 2014, 150, 192-208. [CrossRef]

20. Lv, W.; Wang, Z.; Cao, H.; Sun, Y.; Zhang, Y.; Sun, Z. A Critical Review and Analysis on the Recycling of Spent Lithium-Ion Batteries. ACS Sustain. Chem. Eng. 2018, 6, 1504-1521. [CrossRef]

21. Velazquez, O.; Valio, J.; Santasalo-Aarnio, A.; Reuter, M.; Serna, R. A Critical Review of Lithium-Ion Battery Recycling Processes from a Circular Economy Perspective. Batteries 2019, 5, 68. [CrossRef]

22. Lebedeva, N.; Di Persio, F.; Boon-Brett, L. Lithium ion battery value chain and related opportunities for Europe. Eur. Comm. Petten 2016. [CrossRef]

23. Devasahayam, S.; Dowling, K.; Mahapatra, M.K. Sustainability in the Mineral and Energy Sectors; CRC Press: Boca Raton, FL, USA, 2016; ISBN 978-1-4987-3306-9.

24. Joulié, M. Mécanisme de Dissolution de Matériaux Actifs D'électrodes de Type LiNi1/3Mn1/3Co1/3O2 D'accumulateurs Li-ion en vue de Leur Recyclage; Ecole nationale supérieure de chimie: Montpellier, France, 2015.

25. Allison, J.; Brown, D.; Novo-Gradac, K. MINTEQA2/PRODEFA2, a Geochemical Assessment Model for Environmental Systems: Version 3. 0 User's Manual; US Environmental Protection Agency: Washington, DC, USA, 1991.

26. Laboulle, C. Granulométrie et Exemples D'impacts en Fabrication. Ph.D. Thesis, Université Lille 2 Droit et santé, Lille, France, 2012.

27. Thompson, M. Handbook of Inductively Coupled Plasma Spectrometry; Springer Science \& Business Media: Berlin, Germany, 2012; ISBN 1-4613-0697-3.

28. Pourbaix, M.; Burbank, J. Atlas d'Equilibres Electrochimiques; John Wiley \& Sons, Ltd.: Hoboken, NJ, USA, 1963 ; Volume 14.

29. Djoudi, N.; Le Page Mostefa, M.; Muhr, H. Influence of Temperature on Cobalt Hydroxide Precipitation for Recovery from Battery Leachates. Chem. Eng. Technol. 2021. [CrossRef]

30. Huang, J.; Kargl-Simard, C.; Oliazadeh, M.; Alfantazi, A. pH-Controlled precipitation of cobalt and molybdenum from industrial waste effluents of a cobalt electrodeposition process. Hydrometallurgy 2004, 75, 77-90. [CrossRef]

31. Barbaroux, R. Développement d'un Procédé Hydrométallurgique de Récupération du Nickel. Ph.D. Thesis, National Polytechnic Institute of Lorraine (INPL), Vandoeuvre-les-Nancy, France, 2010.

32. Rickelton, W.; Nucciarone, D. The treatment of cobalt/nickel solutions using Cyanex extractants. Hydrometall. Refin. Nickel Cobalt 1997, 275-292.

33. Tedjar, F.; Foudraz, J.-C. Method for the Mixed Recycling of Lithium-Based Anode Batteries and Cells. U.S. Patent 7,820,317, 26 October 2010.

34. Zhang, P.; Yokoyama, T.; Itabashi, O.; Suzuki, T.M.; Inoue, K. Hydrometallurgical process for recovery of metal values from spent lithium-ion secondary batteries. Hydrometallurgy 1998, 47, 259-271. [CrossRef]

35. Liu, Z.; Ma, R.; Osada, M.; Takada, K.; Sasaki, T. Selective and Controlled Synthesis of $\alpha$ - and $\beta$-Cobalt Hydroxides in Highly Developed Hexagonal Platelets. J. Am. Chem. Soc. 2005, 127, 13869-13874. [CrossRef]

36. Huang, Z.; Zhao, Y.; Song, Y.; Li, Y.; Wu, G.; Tang, H.; Zhao, J. Study on the oxidation process of cobalt hydroxide to cobalt oxides at low temperatures. RSC Adv. 2016, 6, 80059-80064. [CrossRef]

37. Figlarz, M.; Guenot, J.; Tournemolle, J.-N. Oxidation of cobalt (II) hydroxide to oxide hydroxide: Solids evolution during reaction. J. Mater. Sci. 1974, 9, 772-776. [CrossRef]

38. Pralong, V.; Delahaye-vidal, A.; Beaudoin, B.; Grand, B.; Tarascon, J. Oxidation mechanism of cobalt hydroxide to cobalt oxyhydroxide. J. Mater. Chem. 1999, 9, 955-960. [CrossRef]

39. Kanie, K.; Tsujikawa, Y.; Muramatsu, A. Direct Hydrothermal Synthesis of Size-Controlled Co3O4 Nanocubes under Highly Condensed Conditions. Mater. Trans. 2017, 58. [CrossRef]

40. Djoudi, N.; Le Page Mostefa, M.; Muhr, H. Precipitation of Cobalt Salts for Recovery in Leachates. Chem. Eng. Technol. 2019, 42, 1492-1499. [CrossRef]

41. Suksomboon, M.; Srimuk, P.; Krittayavathananon, A.; Luanwuthi, S.; Sawangphruk, M. Effect of alkaline electrolytes on the charge storage capacity and morphology of porous layered double cobalt hydroxide-coated graphene supercapacitor electrodes. RSC Adv. 2014, 4, 56876-56882. [CrossRef] 